\title{
Spawn and early development of two sympatric species of the genus Doriopsilla (Opisthobranchia: Nudibranchia) with contrasting development strategies
}

\author{
Cláudia Soares and Gonçalo Calado \\ Centro de Modelação Ecológica, IMAR. FCT/UNL Quinta da Torre 2825-114 Monte da Caparica, Portugal \\ and Instituto Português de Malacologia. Zoomarine, E.N. 125, km 65. Guia. 8200-864, Albufeira, Portugal \\ (e-mail: ipm@zoomarine.pt).
}

\begin{abstract}
Doriopsilla areolata and $D$. pelseneeri are two very similar species that co-exist in the same habitat but contrast in their reproductive modes. The animals were collected in two different locations of Portugal and Spain, and were kept in the lab for reproduction and subsequent observation of the early development. The egg masses of both species consist of gelatinous flat ribbons coiled regularly. $D$. areolata pre-larval development was about 11-12 days, hatching a planktotrophic larva. In the case of $D$. pelseneeri, the development was direct with a juvenile hatching from the egg after 26-27 days. The different type of development could explain the wide geographic dispersion of $D$. areolata in comparison with the restricted distribution of $D$. pelseneeri.
\end{abstract}

Keywords: Spawn; Development; Doriopsilla; Nudibranchia

\section{INTRODUCTION}

Doriopsilla areolata Bergh, 1880 and Doriopsilla pelseneeri d'Oliveira, 1895 are two radula-less porostomate nudibranchs inhabiting European (Atlantic and Mediterranean) waters. These two species are among the most common nudibranchs found along Portuguese coasts.

The major traits that distinguish both species are dorsal tubercular morphology, shape of the penial hooks and body colour (Valdés and Ortea, 1997). Whereas $D$. areolata has a body colour that varies from yellow to pale brown with white rings or lines in a confused network and with the central dorsum showing a darker tone, $D$. pelseneeri has a body colour that varies from white to red with a white ring on the edge of the gill pocket and the dorsum covered by large, irregular warts stiffened by spicules (Valdés and Ortea, 1997).

The geographic distribution of $D$. areolata extends from the Northern coast of Spain to the Cape Verde Islands, including the Mediterranean Sea. The geographic range of $D$. pelseneeri is more restricted: to the best of our knowledge, this species exists only along the Iberian Peninsula from the North Atlantic coast of Spain to Portugal and the Mediterranean coast of Spain and France (Valdés and Ortea, 1997). Recently it was also found on the French Atlantic coast, close to the Spanish border (Bielecki, 2001).

Preliminary observations revealed that $D$. areolata and $D$. pelseneeri are sympatric nudibranchs with different reproductive modes. The aim of this paper is to compare the larval development of both species.

\section{MATERIALS AND METHODS}

Animals of both species were collected from two localities along the Arrabida coast, West Portugal: Arflor $\left(38^{\circ} 30^{\prime} 24^{\prime \prime} \mathrm{N}-08^{\circ} 55^{\prime} 09^{\prime \prime} \mathrm{W}\right)$ and Outão (38 $\left.29^{\prime} 36^{\prime \prime} \mathrm{N}-08^{\circ} 55^{\prime} 42^{\prime \prime} \mathrm{W}\right)$; and from four localities along Ria de Ferrol, Galicia, Spain: Punta Cariño $\left(43^{\circ} 28^{\prime} 08^{\prime \prime} \mathrm{N}-08^{\circ} 18^{\prime} 50^{\prime \prime} \mathrm{W}\right)$, Segaño $\left(43^{\circ} 27^{\prime} 24^{\prime \prime} \mathrm{N}-\right.$ $\left.08^{\circ} 18^{\prime} 25^{\prime \prime} \mathrm{W}\right)$, Rabo de Porca $\left(43^{\circ} 27^{\prime} 48^{\prime \prime} \mathrm{N}-\right.$ $\left.08^{\circ} 17^{\prime} 58^{\prime \prime} \mathrm{W}\right)$ and Punta Fornelos $\left(43^{\circ} 28^{\prime} 02^{\prime \prime} \mathrm{N}-\right.$ $08^{\circ} 18^{\prime} 40^{\prime \prime} \mathrm{W}$ ). All the specimens were collected by scuba diving at 5-15 $\mathrm{m}$ depth from March to July of 2003 , in the peak of their reproduction period.

Animals were maintained in aerated aquaria with a closed seawater system at a temperature between $17-21^{\circ} \mathrm{C}$ in individually isolated compartments. Specimens were paired periodically for copulation. After approximately one week egg masses were laid and removed immediately. In order to estimate the number of eggs, all spawn were measured (top, base length, and width).

We collected $61 \mathrm{D}$. areolata and $39 \mathrm{D}$. pelseneeri from which it was possible to study 43 and 21 laid egg masses respectively.

In $D$. areolata, three $1 \mathrm{~mm}$ wide transverse sections of the egg masses were cut for observation under a power microscope. In $D$. pelseneeri, spawns were observed intact under a stereoscopic microscope. Right after ovoposition, before any cleavage was observed, eggs were counted in a known egg mass area and measured to estimate egg number per egg mass and egg volume. Egg masses were maintained in $800-1000 \mathrm{ml}$ glass beakers with seawater that 
was changed daily. In the case of D. areolata, the shells of hatched veligers were measured under the power microscope.

All developmental events were documented in photos with a camera incorporated in both microscopes. Development events were described using the classic terminology, as proposed by Gibson (2003), Hadfield and Switzer-Dunlap (1984), Murillo and Templado (1998), and Thompson (1958).

\section{RESULTS}

The egg mass of $D$. areolata formed a spirally coiled flat ribbon whose top was larger than the base length. Eggs could be observed with one or two embryos per capsule and were displayed in parallel lines organized in a few layers inside the egg mass. The colour of the eggs seemed to depend on the colour of the progenitor, undivided eggs varying from yellow to orange. They measured on average $108.3 \pm 7.11 \mathrm{~mm}$ long and $99.69 \pm 6.76 \mathrm{~mm}$ wide $(n=8)$ at right angles. The egg number per egg mass was estimated to be between 5,500 - 240,000 eggs $(n=43)$. It was observed that egg development was unsynchronized, with the eggs at the outer layers developing faster than the eggs in the inner layers. The chronology of major developmental events is summarized in Table 1 and illustrated in Figure 1.

This species presented a very fast initial development. Right after complete ovoposition we could observe two to three different stages of development in the same spawn. The first part to be released could show $2^{\text {nd }}$ cleavage ( 4 cells) by the time the later eggs were coming out of the oviduct, still undivided. So the phase of undivided eggs to $4^{\text {th }}$ cellular division occurred during day 0 .

On day 1 , the stages from morula to blastula were observed. Gastrulation was seen on day 2 . The next day, we could begin to observe the larval forms without cilia or already ciliated but without any detectable movement. They only began moving by the fourth day (pre-veligers), and a ciliated velum was clearly distinguishable. Only on day 5 could we designate them as true veligers because a shell and a bilobed velum could be clearly seen. In this stage veligers were very active inside the capsules. The next stage occurred between days 6 and 7 , in which it was possible to distinguish clearly the statocysts and a developed foot. On days 8 and 9, developed veligers could be observed in which organs such as digestive gland, stomach, intestine, anal gland and retractile muscles were distinct.

Hatching of planktotrophic veligers occurred 11 to 12 days after ovoposition. At this time, larval shells measured on average $171.55 \pm 9.84 \mathrm{\mu m}$ in length $(n=55)$.

The egg mass of $D$. pelseneeri also presented the form of a flat ribbon spirally coiled but with a large quantity of gelatinous matrix, giving a certain resistance and rigidity to the egg mass. Eggs were laid one per capsule in parallel lines as a single layer. The number of eggs per mass was estimated to be between $300-5,000(n=21)$. Compared with the preceding species, $D$. pelseneeri development was slower and almost synchronous within each egg mass. Undivided eggs presented an orange or white colour if belonging to an orange or white animal, respectively, and measured an average of $271.0 \pm 18.75 \mathrm{~mm}$ long and $251.25 \pm 20.27 \mathrm{~mm}$ wide $(n=21)$. The chronology of major developmental events is summarized in Table 2 and illustrated in Figure 2. Contrary to $D$. areolata, the eggs of this species did not begin any visible cleavage right after ovoposition, but only a few hours later. Second division was observed the day after and the third some hours later. So the period from undivided eggs to the fourth cleavage was 2 to 3 days. By the third day, the stage of morula was recognized, and blastula was observed only 2 or 3 days after (on day 6). Gastrula was visible at day 7 or 8 . About day 10 , a rather developed larva was observed with vestigial velum and shell but without any apparent movement. The next day, a formed shell was already present and some larval movement was observed. On day 12, the velum and the foot were formed and on day 14 a developed larva was

Table 1 Chronological sequence of embryonic development of $D$. areolata cultured at $18^{\circ} \mathrm{C}$. See text for details.

\begin{tabular}{cl}
\hline Days & Development Stages \\
\hline 0 & Undivided egg $-4^{\text {th }}$ cleavage \\
1 & Morula to blastula \\
2 & Gastrula \\
3 & Larvae without visible cilia or ciliated without movement \\
4 & Pre-veligers with movement \\
5 & Veliger with bilobed velum and shell \\
$6-7$ & Veliger with statocysts and developed foot \\
$8-9$ & Veliger completely developed with identifiable organs \\
$11-12$ & Hatching
\end{tabular}




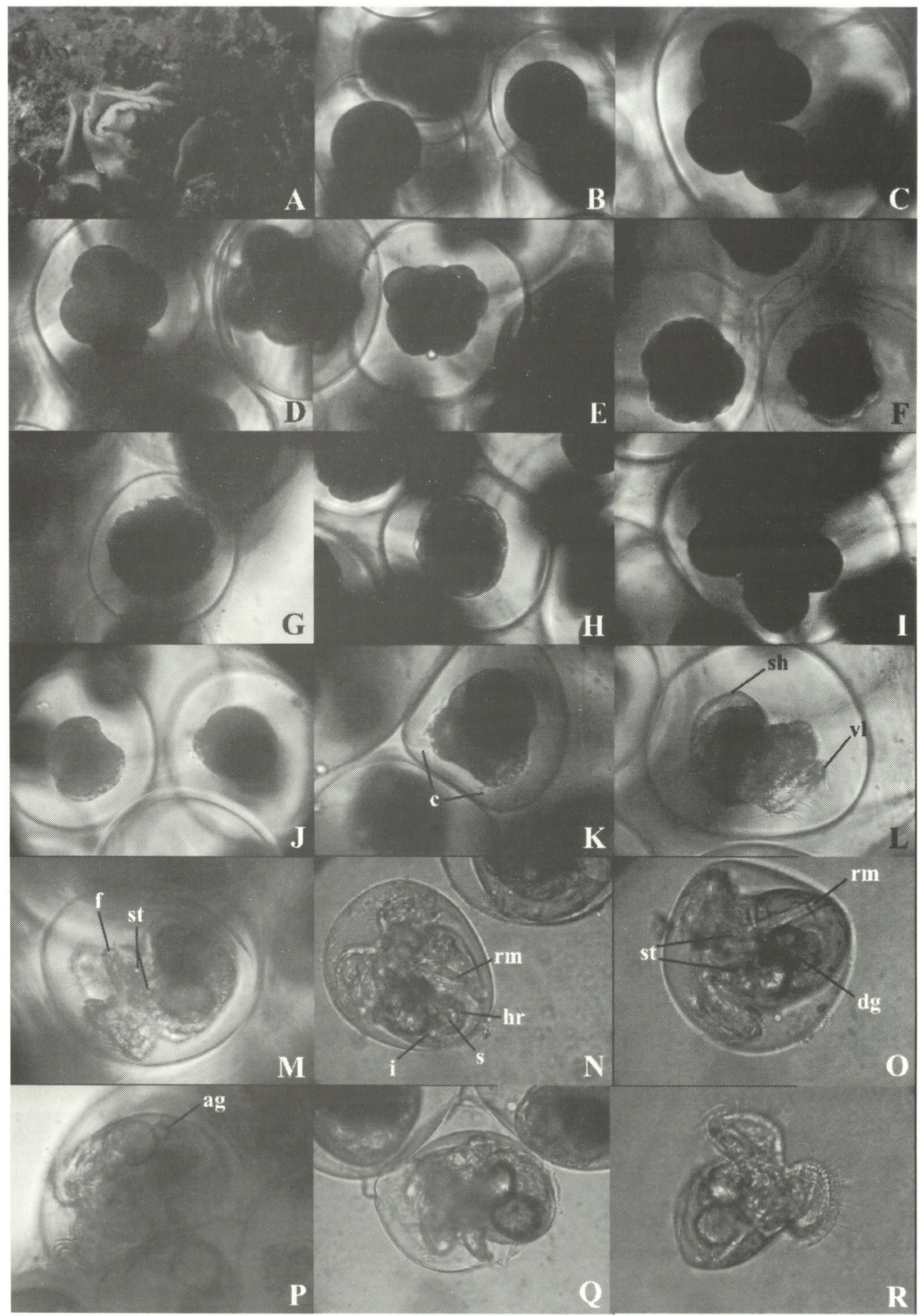

Figure 1 D. areolata developmental stages: A: Egg mass laid in the natural habitat; B: Undivided eggs, just after ovoposition; C: $1^{\text {st }}$ cleavage (two-celled stage); D: $2^{\text {nd }}$ cleavage (four celled stage); E: $3^{\text {rd }}$ cleavage (eight-celled stage); F: $4^{\text {th }}$ cleavage (sixteen- celled stage); G: Morula stage; H: Blastula stage; I: Gastrula stage; J: Ciliated larva without movement; K: Pre-veliger with visible cilia (c); L: Veliger at day 5 with a shell (sh) and bilobed velum (vl); M: Veliger at day 6-7 with a developed foot (f) and statocysts (st), N, O and P: Developed veliger with identifiable organs like anal gland (ag), digestive gland (dg), hyaline rods (hr), intestine (i), retractile muscles (rm) and stomach (s); Q: Hatching veligers; R: Veliger just after hatching. 


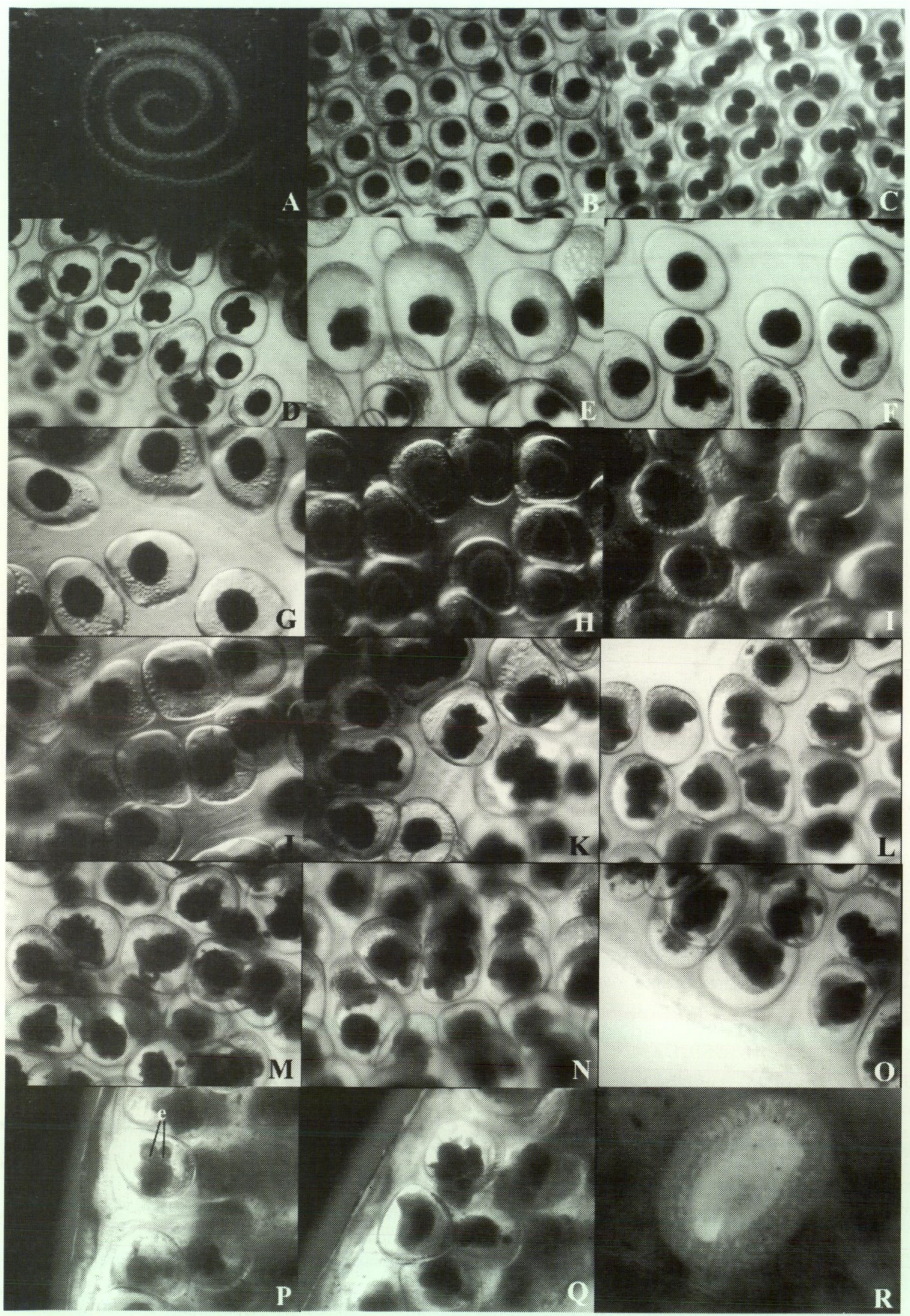

Figure 2 D. pelseneeri developmental stages: A: Egg mass laid in the natural habitat; B: Undivided eggs, just after ovoposition; C: $1^{\text {st }}$ cleavage (two-celled stage); D: $2^{\text {nd }}$ cleavage (four celled stage); E: $3^{\text {rd }}$ cleavage (eight-celled stage); F: $4^{\text {th }}$ cleavage (sixteen- celled stage); G: Blastula stage; H: Gastrula stage; I: Early veliger with velum and early shell; J: Veliger with slight movement and formed shell; K: Veliger with developed velum and foot; L: Veliger apparently developed with formed organs; M: Beginning of metamorphosis; N and O: Stage where velum is reduced, mantle expands laterally, body elongates and shell is not visible; P: Eyes (e) are visible; Q: Juvenile ready to hatch; R: Juvenile after hatching. 
Table 2 Chronological sequence of embryonic development of $D$. pelseneeri cultured at $18^{\circ} \mathrm{C}$. See text for details.

\begin{tabular}{cl}
\hline Days & Development Stages \\
\hline 0 & Undivided egg $-1^{\text {st }}$ cleavage \\
1 & $2^{\text {nd }}$ cleavage $-3^{\text {rd }}$ cleavage \\
2 & $4^{\text {th }}$ cleavage \\
3 & Morula \\
$5-6$ & Blastula \\
$7-8$ & Gastrula \\
10 & Early veliger with velum and early shell \\
11 & Veliger with slight movement and formed shell \\
12 & Veliger with developed velum and foot \\
14 & Veliger apparently developed with formed organs \\
19 & Metamorphosis starts \\
22 & Velum reduced, mantle lateral expansion, body elongation and shell is not visible \\
25 & Final metamorphosis - visible eyes and juveniles inside capsules \\
$26-27$ & Hatching \\
\hline
\end{tabular}

observed with the organs formed. Nevertheless, we were unable to distinguish them clearly because these larvae were very opaque. At this stage larvae possessed some movement but far less than the frenetic larval movement of $D$. areolata. On day 19, intra-capsular metamorphosis was initiated. A slight change in the typical veliger form was first noted. Three days later (day 22), the velum began to diminish proportionally to the larval body. The larval body also started to elongate and expand laterally. The larval shell was no longer observed. The final stage of metamorphosis was seen in day 25 when we could clearly distinguish the eyes and some completely formed juveniles were seen still inside the capsules. Juveniles started hatching about 26-27 days after ovoposition, first inside the jelly matrix and a few days later outside. These juveniles were orange or white, always matching the colour of the spawn mass and of their progenitor. They measured about $1 \mathrm{~mm}$ in length (Figure $2 \mathrm{R}$ ).

\section{DISCUSSION}

Doriopsilla areolata and $D$. pelseneeri exhibit different modes of development although as adults they coexist in the same habitat. It has been shown for many sympatric species of opisthobranchs that differences in their development mode are common, and as pointed out by Hadfield and Miller (1987), species that nowadays live in sympatry might have not have evolved under the same conditions or in the same geographical areas.

Spawn type for both species, observed in the present study, corresponded to type $\mathrm{A}$ as defined by Hurst (1967), with a coiled ribbon shape attached by one of the margins. This type of spawn is not only typical of dorid but also of aeolid nudibranchs (Hadfield and Switzer-Dunlap, 1984).

Valdés and Ortea (1997) state that D. pelseneeri juveniles' hatch with a white body colour and that colour changes respectively to yellow, orange and red as individuals grow. This ontogenetic change in colouration does not agree completely with our observations, as our newly hatched juveniles already had a slight orange colouration. Also, when comparing adults collected in Spain and Portugal, we found individual animals of similar size with different body colours. The animals from Portugal were mostly orange in colour (only one dark yellow specimen was observed) whereas the ones from north-west Spain were white, sometimes slightly pinkish in the centre, or orange like their southern counterparts, regardless of body size. To date, no white $D$. pelseneeri have been observed in Arrábida (Portugal).

In light of present data, $D$. areolata most certainly has a planktotrophic development while $D$. pelseneeri has direct, metamorphic development with individuals that hatch as juveniles. Table 3 , summarizes egg mass and some early development data available in the literature for species of Doriopsilla. Values for egg diameter given by Ballesteros and Ortea (1980), Sánchez-Tocino (2003) and Valdés and Ortea (1997) on the D. areolata spawn are not very different from our observations. Together with the Eastern Pacific D. albopunctata, these are the only Doriopsilla species for which a planktotrophic development is known so far. $D$. pelseneeri data can be compared with data of other Doriopsilla species with direct development. In this case, some resemblance in the spawns is clear, as far as both egg diameter and number of eggs per spawn mass are concerned. It is worth noting that Doriopsilla miniata has a capsular ametamorphic development, while Doriopsilla pharpa has a capsular metamorphic development just like $D$. pelseneeri. Gosliner (1987) and Thompson (1975) suggested that $D$. areolata and $D$. miniata might be synonymous because of their similar external appearance. Nonetheless, data provided by Rose 
Table 3 Summary of reproductive data for Doriopsilla species.

\begin{tabular}{|c|c|c|c|c|}
\hline Species & $\begin{array}{l}\text { Development } \\
\text { mode }\end{array}$ & $\begin{array}{l}\text { Egg diameter } \\
(\mu \mathrm{m})\end{array}$ & $\begin{array}{l}\text { Number of eggs } \\
\text { per spawn }\end{array}$ & Source \\
\hline Doriopsilla areolata & Planktotrophic & $\begin{array}{c}99-118 \\
132 \text { (average value) } \\
88-90 \\
96-121\end{array}$ & $\begin{array}{c}5500-240000 \\
- \\
- \\
-\end{array}$ & $\begin{array}{c}\text { Present study } \\
\text { Ballesteros \& Ortea, } 1980 \\
\text { Sánchez-Tocino, } 2003 \\
\text { Valdés \& Ortea, } 1997\end{array}$ \\
\hline Doriopsilla albopunctata & Planktotrophic & $100-150$ & - & Gosliner et al., 1999 \\
\hline Doriopsilla gemela & Lecitotrophic & $120-300$ & $\sim 2000$ & Gosliner et al., 1999 \\
\hline Doriopsilla pelseneeri & Direct & $240-303$ & $300-5000$ & Present study \\
\hline Doriopsilla pharpa & Direct & 213 (average) & 1050 (average) & $\begin{array}{c}\text { Clark \& Goetzfried, } 1978 \\
\text { in Ros, } 1981\end{array}$ \\
\hline & & 203 (average value) & $21-1090$ & $\begin{array}{c}\text { Eyster, 1977; } \\
\text { Eyster \& Stancyk, } 1981\end{array}$ \\
\hline Doriopsilla miniata & Direct & $225-231$ & $412-550$ & Rose, 1984 \\
\hline
\end{tabular}

(1985), Benkendorff (2003), and in the present study reinforce the differences between the two species concerning the development type and spawn mass characteristics.

So we may generalize like Rose (1984) and Rudman and Willan (1998), in which species with planktotrophic larvae are characterized by having small eggs (30-170 $\mu \mathrm{m})$ with a larger number per egg mass (420-242,000), with shorter development period (5-11 days) and eggs are often encapsulated in groups of more than 2 embryos (2-11 per capsule). Species with direct development are characterized by having large eggs (more than $200 \mu \mathrm{m}$ ), with fewer eggs per mass $(150-2,664)$ and with a longer development period (15-20 days).

During the development of $D$. areolata a feeble synchrony between inner and outer embryos in the spawn was observed. This spawn being a compact egg mass with embryos at different layers reduces the surface exposed to water. This can possibly give a greater protection with less extra-embryonic protective material at the same time reducing the parental energy invested per generation. On the other hand, the exchanges of oxygen and wastes with the surrounding can be limited in this type of spawn. So with slower exchange rates, development may be retarded for interior embryos resulting in an asynchronous embryonic development. Also current velocity can influence development synchrony. A high current velocity minimizes the lack of oxygen in central embryos (Chaffee and Strathmann, 1984). So some asynchrony could have been avoided if the spawns were maintained in a circuit with flowing water. The necessary sectioning of the spawn masses for microscope observation might have had some effect in the observation of this phenomenon, in the way it exposed inner parts of the spawns that otherwise, by the reasons cited previously, would have a slower development than the one it actually did. Anyway, the same kinds of differences between inner and outer layers were also visible in complete (not sectioned) egg masses.

The essential time to achieve juvenile stage varies in several ways between development modes. The first variation is the time wasted in embryonic development, being generally shorter for planktotrophic species and longer for the ones with direct development (Hadfield and Miller, 1987). As it was observed in the present work, $D$. areolata with planktotrophic development spent approximately half the time till hatching than did $D$. pelseneeri with direct development.

Potential dispersion capability of a species is dependent on many physical and biological habitat conditions. Planktotrophic species have a high fecundity and great dispersal potential. On the other hand species with direct development have a reduced fecundity with higher larval stage protection and limited dispersion capability. They hatch and settle in the same places where their progenitors live. Such phenomenon is verified in the two species herein studied. $D$. areolata with planktotrophic development has a wide geographic dispersion while $D$. pelseneeri with direct development has a much more restricted distribution, mostly limited to the Iberian Peninsula. Since both species fed on a variety of sponges widespread in the Lusitanian province (Calado, personal observation), no host constraint should be involved in their actual distribution.

\section{ACKNOWLEDGEMENTS}

G.C. holds a grant from the Fundação para a Ciência e Teconologia, Portugal (BPD7133/2001). António Monteiro read an early version of the manuscript suggesting a number of textual corrections. This manuscript was presented as part of an oral communication at the opisthobranch symposium held during the World Congress of Malacology, Perth, July 2004. 


\section{REFERENCES}

Ballesteros, M. and Ortea, J. (1980). Contribución al conocimiento de los Dendrodorididae (Moluscos, Opistobranquios, Doridácios) del litoral ibérico. 1. Publicaciones del Departamento de Zoología, Universidad de Barcelona 5: 25-37.

Benkendorff, K. (2003). Doriopsilla miniata and its eggribbons. [Message in] Sea Slug Forum, Australian Museum, Sydney. http://seaslugforum.net/ display.cfm?id=10469 Last accessed Feb 6 $6^{\text {th }}, 2006$.

Bielecki, J-P. (2001). Yellow dorid from SW France. [Message in] Sea Slug Forum. Australian Museum, Sydney. Available from http:// www. seaslugforum.net/find.cfm?id $=3991$. Last accessed Feb $6^{\text {th }}, 2006$.

Chaffee, C. and Strathmann, R.R. (1984). Constraints on egg masses. I. Retarded development within thick egg masses. Journal of Experimental Marine Biology and Ecology 84: 73-83.

Eyster, L.S. and Stancyk, S.E. (1977) Reproduction and growth of the nudibranch Doriopsilla pharpa in North Inlet, South Carolina. American Society of Zoologists 17 (4): 948.

Eyster, L.S. and Stancyk, S.E. (1981). Reproduction, growth and trophic interactions of Doriopsilla pharpa Marcus in South Carolina. Bulletin of Marine Science 31 (1): 72-82.

Gibson, G.D. (2003). Larval development and metamorphosis in Pleurobranchea maculata, with a review of development in Notaspidea (Opisthobranchia). Biological Bulletin 205: 121-132.

Gosliner, T. (1987). Nudibranchs of Southern Africa. Sea Challengers, Monterey, California. $136 \mathrm{pp}$.

Gosliner, T. M., Schaefer, M.C. and Millen, S.V (1999). A new species of Doriopsilla (Nudibranchia: Dendrodorididae) from the Pacific coast of North America, including a comparison with Doriopsilla albopunctata (Cooper, 1863). The Veliger 42: 201-210.
Hadfield, M. G. and Switzer-Dunlap, M. (1984). Opisthobranchs. In A. S. Tompa, N. H. Verdonk and J. A. M. van den Biggelaar (eds), The Mollusca (Reproduction). New York, Academic Press. 7: 209350.

Hadfield, M. G. and Miller, S. E. (1987). On developmental patterns of opisthobranchs. American Malacological Bulletin 5 (2): 197-214.

Hurst, A. (1967). The egg masses and veligers of thirty northeast Pacific opisthobranchs. The Veliger 9: 255288.

Murillo, L. and Templado, J. (1998). Spawn and development of Bulla striata (Opisthobranchia, Cephalaspidea) from the Western Mediterranean. Iberus 16 (2): 11-19.

Ros, J., (1981). Desarollo y estrategias bionómicas en los opistobranquios. Oecologia Aquatica 5: 147-183.

Rose, R. A. (1984). The spawn and development of twenty-nine New South Wales opisthobranchs (Mollusca: Gastropoda). Proceedings of the Linnean Society of New South Wales 108 (1): 23-36.

Rudman, W.B. and Willan, R. (1998). Opisthobranchia introduction. In P.L. Beesley, G.J.B. Ross and A. Wells, (eds), Mollusca: The Southern Synthesis. Fauna of Australia. CSIRO Publishing, Melbourne 5 (Part B): 915-942.

Sánchez-Tocino, L. (2003). Aspectos taxonómicos y biológicos de los Doridoidea (Mollusca: Nudibranchia) del litoral Granadino. PhD Tesis, Universidad de Granada.

Thompson, T. E. (1958). The natural history, embryology, larval biology and post-larval development of Adalaria proxima (Alder \& Hancock) (Gastropoda: Opisthobranchia). Philosophical Transactions of the Ray Society - Series B 242: 1-58.

Thompson, T. E. (1975). Dorid nudibranchs from Eastern Australia. Journal of Zoology, London, 176: 477-517.

Valdés, A. and Ortea, J. (1997). Review of the genus Doriopsilla Bergh, 1880 (Gastropoda: Nudibranchia) in the Atlantic Ocean. The Veliger 40 (3): 240-254. 